\title{
Toxoplasma gondii and Neospora caninum infections in synanthropic rodents from Argentina
}

\author{
Infecçóes por Toxoplasma gondii e Neospora caninum em roedores sinantrópicos da Argentina \\ Andrea Dellarupe ${ }^{1,2}$ (D); Bruno Fitte ${ }^{3}$ (D); Lais Pardini ${ }^{1,2}$ (D); Lucía María Campero ${ }^{1,2}$ (D); Mariana Bernstein ${ }^{1,2}$ (DD; \\ María del Rosario Robles ${ }^{3}$ (D); Gastón Moré ${ }^{1,2 *}$ (D); María Cecilia Venturini ${ }^{1}$; Juan Manuel Unzaga ${ }^{1}$ (D) \\ ${ }^{1}$ Laboratorio de Inmunoparasitología - LAINPA, Facultad de Ciencias Veterinarias, Universidad Nacional de La Plata - UNLP, \\ La Plata, Argentina \\ ${ }^{2}$ Consejo Nacional de Investigaciones Científicas y Técnicas - CONICET, Ciudad Autónoma de Buenos Aires, Argentina \\ ${ }^{3}$ Centro de Estudios Parasitológicos y de Vectores - CEPAVE, Centro Científico Tecnológico La Plata, Consejo Nacional de \\ Investigaciones Científicas y Técnicas - CONICET, Universidad Nacional de La Plata - UNLP, La Plata, Buenos Aires, Argentina
}

Received October 19, 2018

Accepted January 21, 2019

\begin{abstract}
Toxoplasma gondii and Neospora caninum are closely related coccidian parasites (phylum Apicomplexa). This is the first study from urban synanthropic rodent species that involved serological and molecular diagnosis of T. gondii and $N$. caninum infection, and genotyping of T. gondii in Argentina. A total of 127 rodent samples were trap captured: Mus musculus $(n=78)$, Rattus norvegicus $(n=26)$ and Rattus rattus $(n=23)$. Antibodies against $T$. gondii and $N$. caninum were detected by IFAT in $32.8 \%$ (40/122) and $0.8 \%$ (1/122) of rodent samples, respectively, demonstrating contact with these protozoans. Additionally, T. gondii DNA was detected in 3.3\% (4/123) of rodent central nervous system samples and 2 samples were genotyped by multilocus nPCR-RFLP. Neospora caninum DNA was not detected by PCR. The 2 genotyped samples were type III allele for all markers except for SAG-1 (type I for Rat1Arg and type II/III for Rat2Arg) and were identified as \#48 and \#2 (likely) according to the allele combinations reported on Toxo DB (Toxo-DB). The results of the present study revealed a wide distribution of T. gondii and less for $N$. caninum, in synanthropic rats and mice in the studied area.
\end{abstract}

Keywords: Toxoplasma gondii, Neospora caninum, synanthropic rodent, serology, genotyping.

\section{Resumo}

Toxoplasma gondii e Neospora caninum são parasitas coccídeos intimamente relacionados (filo Apicomplexa). Este é o primeiro estudo de espécies de roedores sinantrópicos urbanos, o qual envolveu diagnósticos sorológicos e moleculares da infecção por T. gondii e N. caninum e genotipagem de T. gondii na Argentina. Um total de 127 amostras de roedores foram obtidas: Mus musculus $(\mathrm{n}=78)$, Rattus norvegicus $(\mathrm{n}=26)$ e Rattus rattus $(\mathrm{n}=23)$. Anticorpos contra T. gondii $\mathrm{e}$ $N$. caninum foram detectados pela IFAT em 32,8\% (40/122) e 0,8\% (1/122) das amostras de roedores, respectivamente, demonstrando contato com esses protozoários. Adicionalmente, o DNA de T. gondii foi detectado em 3,3\% (4/123) das amostras do sistema nervoso central de roedores e duas amostras foram genotipadas por nPCR-RFLP multilocus. O DNA de $N$. caninum não foi detectado por PCR. As 2 amostras genotipadas eram do tipo III para todos os marcadores, exceto para SAG-1 (tipo I para Rat1Arg e tipo II / III para Rat2Arg) e foram identificadas como \# 48 e \# 2 (provavelmente) de acordo com as combinaçóes de alelos relatadas no Toxo DB (Toxo-DB). Os resultados do presente estudo indicam uma ampla distribuição de T. gondii e menor para $N$. caninum, em ratos e camundongos sinantrópicos na área estudada.

Palavras-chave: Toxoplasma gondii, Neospora caninum, roedor sinantrópico, sorologia, genotipagem.

\section{Introduction}

Toxoplasma gondii and Neospora caninum are closely related coccidian parasites (phylum Apicomplexa), with facultative heteroxenous life cycle, with felids and canids as definitive hosts

*Corresponding author: Gastón Moré. Laboratorio de Inmunoparasitología, Facultad de Ciencias Veterinarias, Universidad Nacional de La Plata, calle 60 y 118 (1900), La Plata, Argentina. e-mail: gastonmore@fcr.unlp.edu.ar
(DH), respectively (DUBEY, 2010; DUBEY et al., 2007). They share many common morphological and biological features (DUBEY, 2010; DUBEY et al., 2007). Most infected intermediate host (IH) are asymptomatic and develop chronic stages of infection with tissue cysts located mainly in central nervous system (CNS) and muscles (DUBEY, 2010). Infection in IH and DH can be acquired vertically by transplacental passage of parasites (tachyzoites), 
or horizontally following ingestion of tissues containing cysts (bradyzoites), or food or water contaminated with resistant oocysts excreted in DH feces (DUBEY, 2010).

Toxoplasma gondii is a worldwide distributed zoonotic parasite that infects most mammal and bird species as IH (DUBEY, 2010). Susceptible animals present different clinical signs: neuromuscular disorders in dogs, abortion in small ruminants, stillborn and abortion in pigs and fatal toxoplasmosis in Australian marsupials and New World monkeys (DUBEY, 2010). Clinical signs of human toxoplasmosis include retinal lesions (ocular toxoplasmosis), CNS lesions (mainly associated with congenital toxoplasmosis and immunocompromised patients) and multisystemic failure, especially in immunocompromised patients (WEISS \& KIM, 2014). Toxoplasma gondii population has a complex genetic structure classified by nested PCR restriction fragment length polymorphism (nPCR-RFLP) into three major genotypes named as I, II, and III (clonal or canonical types), plus several additional recombinant or non-clonal (atypical) genotypes. Most isolates of T. gondii obtained from animals and humans in North America and Europe correspond to clonal types, mostly by the clonal type II (DUBEY, 2010; WEISS \& KIM, 2014). In South America the presence of non-clonal isolates of $T$. gondii with high virulence in mouse model has been detected (PENA et al., 2008).

Unlike T. gondii, N. caninum is not a zoonotic disease, with a more restricted host range (DUBEY et al., 2007; MCCANN et al., 2008). Neospora caninum is responsible for neuropathy in dogs, showing a striking capacity for highly efficient vertical transmission in bovines and small ruminants (CAMPERO et al., 2018; DUBEY et al., 2007). Neospora caninum is one of the most important causes of bovine abortion or stillbirth, resulting in significant economic losses to the dairy and beef industries worldwide (DUBEY et al., 2007).

Generally, rodents and other small mammals are considered as one of the sources of $T$. gondii infection for DH (DUBEY, 2010). Synanthropic rodents (Mammalia, Rodentia) are widely distributed around the world. The most important synanthropic rodent species in urban areas are Rattus norvegicus, Rattus rattus and Mus musculus that have an enormous ability to adapt to any terrestrial environment (BRASIL, 2002). These rodents could be infected with T. gondii or N. caninum through oocysts ingestion (DUBEY, 2010; DUBEY et al., 2007). Also, they could play a key role in dissemination of $T$. gondii to other domestic or stray carnivorous/omnivorous animals and to themselves through cannibalism habit (DUBEY, 2010). Congenital transmission of $T$. gondii and $N$. caninum occurs at a high rate when rodent are infected during pregnancy (DELLARUPE et al., 2014; DUBEY \& FRENKEL, 1998).

Several studies reported the occurrence of $T$. gondii natural infection in rodents, by the detection of specific antibodies and/or parasite DNA, or by parasite isolation (DUBEY \& FRENKEL, 1998; YAN et al., 2014). In the case of $N$. caninum, there are only reports of serological study (FERROGLIO et al., 2007; HUANG et al., 2004). However, there is no information about the presence of these protozoans in synanthropic rodents in Argentina.

The aims of the present study were to detect $T$. gondii and $N$. caninum infection in synanthropic rodents by serological and molecular methods and to genetically characterize $T$. gondii from Gran La Plata, Argentina.

\section{Materials and Methods}

\section{Study area}

The samples were collected in Gran La Plata, an area formed by La Plata, Berisso and Ensenada departments situated north-west of Buenos Aires province. It has a population of more than 850000 inhabitants, according to the 2010 census and the official projections (INDEC, 2018). For this study, six areas of La Plata and one of Berisso departments were involved, representing different levels of urbanization. Five areas were neighborhoods situated on the outskirts of La Plata (local names in italics): Malvinas

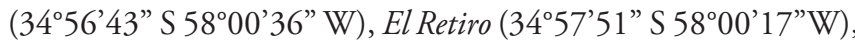

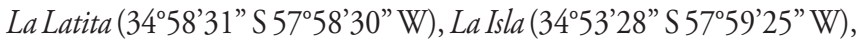
and Abasto (34 $\left.4^{\circ} 58^{\prime} 05^{\prime \prime} S 58^{\circ} 01^{\prime} 47^{\prime \prime} \mathrm{W}\right)$. One representing the

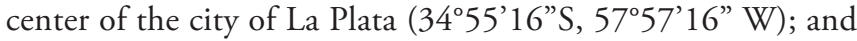
one in a peripheral area of Berisso: El Carmen (34 $55^{\prime} 33^{\prime \prime} \mathrm{S}$ $\left.57^{\circ} 53^{\prime} 09^{\prime \prime} \mathrm{W}\right)$. Most of these areas have socio-structural and environmental issues and inadequate supply of basic urban services, such as garbage removal, sanitation networks, potable water, pavement, areas susceptible to flooding and domestic animals without sufficient care.

\section{Rodent capture}

Rodents were trapped and sampled during September 2014 and September $2015(n=127)$, corresponding to the following species: $M$. musculus $(n=78), R$. rattus $(n=23)$ and $R$. norvegicus $(n=26)$. The animals were captured in Sherman and cage traps. Traps were set in the backyard and inside of the houses offered by habitants of the different areas and were checked daily for 3 days period. The bait used was a mixture made of banana, oat, animal fat, peanut cream, carrots and meat. Sample collection was carried out under official permits granted by Dirección de Flora y Fauna, Ministerio de Asuntos Agrarios de la Provincia de Buenos Aires (expedient N²2500-7981/10). No endangered species were involved in this study. The specimens were obtained with methods of live capture and sacrificed in a $\mathrm{CO} 2$ chamber, following the procedures and protocols approved by national laws (Animal Protection National law 14.346 and references in the provincial permits) and Ethics Committee for research on laboratory, farm and obtained from nature animals of National Council of Scientific and Technical Research (CONICET) (Resolution 1047, section 2, annex II).

\section{Sample collection}

Conventional studies were realized at the Centro de Estudios Parasitológicos y de Vectores (CEPAVE) for the taxonomic identification of the specimens (PRITCHARD \& KRUSE, 1982) and samples were collected at necropsy for further studies. Blood samples were collected by cardiac puncture and the recovered sera were preserved at $-20{ }^{\circ} \mathrm{C}$ for indirect immunofluorescence antibody test (IFAT). Samples of CNS were collected in sterile conditions and preserved at $-20^{\circ} \mathrm{C}$ for PCR and genotyping studies, and 
in $10 \%$ formaldehyde in phosphate buffer solution (PBS) for histopathological studies.

\section{Serological diagnosis}

Sera were tested by IFAT for the detection of antibodies against T. gondii, and N. caninum in Laboratorio de Inmunoparasitología, FCV, UNLP (LAINPA). For T. gondii and N. caninum serology, cell culture-derived tachyzoites of RH strains (DUBEY, 2010) and NC-1 (DUBEY et al., 2007), respectively, were used as antigens and processed as previously described (MORE et al., 2008), using anti-mouse IgG (IgG, whole molecule)-FITC-conjugate (Sigma-Aldrich, St. Louis, USA) for all rodent species samples. Sera were tested at 3 different dilutions: 1/50; 1/200 and 1/800 (HUANG et al., 2004).

\section{PCR diagnosis and genotyping}

DNA was extracted from CNS samples using a commercial kit (Wizard ${ }^{\circledR}$ Genomic DNA Purification Kit, Promega) according to the manufacturer's protocol at LAINPA. The specific PCRs using Tox 5-Tox8 and NP6+-NP21+ primers were used to identify T. gondii and $N$. caninum DNA respectively, as described previously (CAMPERO et al., 2015; MORE et al., 2012). Each amplification routine was conducted with a positive control (DNA from T. gondii RH strain and $N$. caninum Nc-1 strain, respectively), and a negative control (control process sample DNA) and a no template control (NTC).

Genotyping of all $T$. gondii samples was performed by nPCR-RFLP using 10 genetic markers: SAG1, SAG2 (5'3'SAG2, altSAG2), SAG3, BTUB, GRA6, C22-8, C29-2, L358, PK1, and Apico as described previously (MORE et al., 2012; SU et al., 2006). DNA from RH, Me49 and NED T. gondii strains were used as genotype I, II and III controls, respectively. The PCR and nPCR-RFLP products were visualized in $1.5 \%$ and $2.5 \%$ (except for Apico [3\%]) agarose gels (Biodynamics), respectively and stained with SYBR Safe (Invitrogen) using 100 bp standard (Cien Marker, Biodynamics) (MORE et al., 2012).

\section{Histopathology}

Brain samples were fixed in $10 \%$ neutral buffered formalin, and routinely processed for histology and stained with hematoxylin and eosin (H\&E), and examined microscopically for presence of protozoan tissue cysts. This technique was carried out in the CEPAVE.

\section{Results}

\section{Serological diagnosis}

Antibodies against T. gondii were found in 18/77 M. musculus (23.3\%), 7/22 R. rattus (31.8\%) and 15/23 R. norvegicus (65.2\%). From 5 rodents, serum sample was not achieved ( $1 \mathrm{M}$. musculus, $1 R$. rattus and $3 R$. norvegicus). Distribution of positive samples by IFAT at different serum dilutions is shown in Table 1. Antibodies against $N$. caninum were found in only one $M$. musculus of $77(1.3 \%)$ at $1 / 50$ serum dilution, the rest of sera were negative.

\section{PCR and T. gondii genotyping}

The DNA was extracted from CNS of 123 rodents (samples were not available in 4 animals). PCR resulted positive to $T$. gondii in $4 / 123(3.3 \%)$ samples (Table 2), and negative to $N$. caninum in all samples. Antibodies against T. gondii were found in 3 of the PCR-positive animals: 2 rodents ( $1 R$. rattus and $1 R$. norvegicus) were positive at $\geq 1 / 800$, and one rodent $(R$. norvegicus) was positive at $1 / 200$.

Only 2/4 T. gondii PCR-positive samples were successfully genotyped and named Rat1Arg and Rat2Arg. The 2 genotyped samples were type III allele for all markers except for SAG-1 (type I for Rat1Arg and type II/III for Rat2Arg) and were identified as \#48 and \#2 (likely) according to the allele combinations reported on the online server ToxoDB (2018) (Table 3). The samples correspond to the animals with the highest $T$. gondii antibody titer. Genotyping was not successful for the other 2 samples, probably due to the low quantity of $T$. gondii DNA.

Table 1. Toxoplasma gondii IFAT results in samples from synanthropic rodent species.

\begin{tabular}{|c|c|c|c|c|}
\hline Dilution & $1 / 50$ & $1 / 200$ & $1 / 800$ & Total positive \\
\hline$R$. rattus & $\begin{array}{c}4 \\
(18.1 \%)\end{array}$ & $\begin{array}{c}1 \\
(4.5 \%)\end{array}$ & $\begin{array}{c}2 \\
(9.1 \%)\end{array}$ & $\begin{array}{c}7 / 22 \\
(31.8 \%)\end{array}$ \\
\hline R. norvegicus & $\begin{array}{c}4 \\
(17.4 \%)\end{array}$ & $\begin{array}{c}9 \\
(39.1 \%)\end{array}$ & $\begin{array}{c}2 \\
(8.6 \%)\end{array}$ & $\begin{array}{c}15 / 23 \\
(65.2 \%)\end{array}$ \\
\hline M. musculus & $\begin{array}{c}8 \\
(10.4 \%)\end{array}$ & $\begin{array}{c}5 \\
(6.5 \%)\end{array}$ & $\begin{array}{c}5 \\
(6.5 \%)\end{array}$ & $\begin{array}{c}18 / 77 \\
(23.3 \%)\end{array}$ \\
\hline
\end{tabular}

Table 2. Toxoplasma gondii PCR results from CNS samples of synanthropic rodent species.

\begin{tabular}{ccc}
\hline & Positive & Total \\
\hline R. rattus & 1 & 22 \\
R. norvegicus & $(4.5 \%)$ & 26 \\
\\
M. musculus & 2 & \\
& $(9.1 \%)$ & 75 \\
\hline
\end{tabular}


Table 3. Toxoplasma gondii genotyping results from 2 Rattus spp. CNS samples.

\begin{tabular}{cccccccccccccc}
\hline Host name & $\begin{array}{c}\text { Strain } \\
\text { ID }\end{array}$ & $\begin{array}{c}\text { ToxoDB } \\
\text { ID }\end{array}$ & SAG1 & 5-3'SAG2 & $\begin{array}{c}\text { alt. } \\
\text { SAG2 }\end{array}$ & SAG3 & BTUB & GRA6 & C22-8 & C29-2 & L358 & PK1 & Apico \\
\hline $\begin{array}{c}\text { Rat } \\
\begin{array}{c}\text { Rattus rattus) } \\
\text { Rat }\end{array}\end{array}$ & Rat1Arg & ${ }^{*} 48$ & I & III & III & III & III & III & III & III & III & III & III \\
$\begin{array}{c}\text { Rattus norvegicus) } \\
\text { Rat2Arg }\end{array}$ & $\begin{array}{c}{ }_{2} 2 \\
\text { (likely) }\end{array}$ & II/III & nd & III & III & III & III & III & III & III & III & III \\
\hline
\end{tabular}

\#identity number in Toxo-DB; nd = no data.

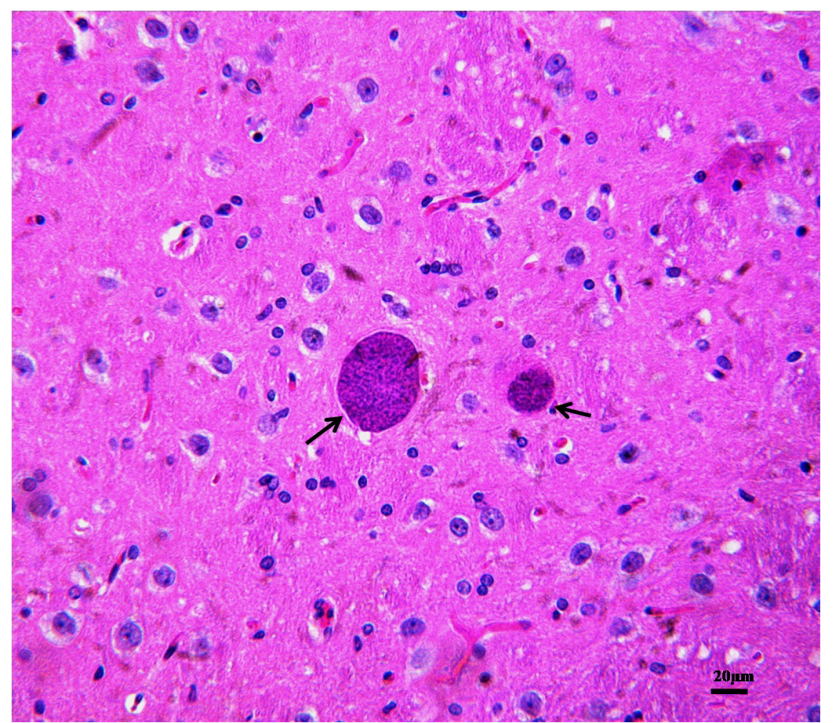

Figure 1. T. gondii cysts (arrows) in a brain section of a rodent (Rat1Arg), H\&E staining.

\section{Histopathology}

Brain samples from 123 rodents (samples were not available in 4 animals), were examined microscopically. Only in one sample (Rat1Arg) protozoan cysts of different sizes, without inflammatory reaction were observed (Figure 1). The brain sample was positive to T. gondii by PCR.

\section{Discussion}

This is the first study from urban synanthropic rodent species in Argentina that involved serological and molecular diagnosis of $T$. gondii and N. caninum infection, and genotyping of T. gondii in the area of Gran La Plata, Buenos Aires, Argentina. Antibodies against $T$. gondii and $N$. caninum were detected by IFAT in $32.8 \%$ $(40 / 122)$ and $0.8 \%(1 / 122)$ of rodent samples, respectively, demonstrating contact with these protozoans. Additionally, T. gondii DNA was detected in 3.3\% (4/123) of rodent CNS samples. On the other hand, $N$. caninum DNA was not detected by PCR. Despite, of the relatively high frequency of anti- $T$. gondii antibodies detection, only 4 rodents were positive by PCR and only in 2 samples T. gondii genotyping was successful. Interestingly, the CNS samples with high T. gondii DNA burden (allowing complete genotyping) correspond to animals with high antibodies titer $(1 / 800)$ and one of them was the unique sample where tissue cysts were observed. Similar results have been obtained in other IH, suggesting that high antibody titer correlate with high parasite burden in tissues. In addition, the 2 samples that were negative and with an intermediate titter $(1 / 200)$ by IFAT resulted positive by PCR, however genotyping was not plausible, suggesting that the amount of $T$. gondii DNA tissues was low. On the other hand, a low percentage of $T$. gondii serologically positive animals resulted also positive by PCR, similar as reported by other authors (RUFFOLO et al., 2016; YAN et al., 2014).

Toxoplasma gondii population from South America shows a higher genetic variability than in North America and Europe. Clonal type III as well as non-clonal T. gondii genotypes are overrepresented in South America (PENA et al., 2008; SHWAB et al., 2014). Recently, the population structure of $T$. gondii in Argentina was analyzed, and 39 samples from animals and humans were genotyped using nPCR-RFLP and classified according ToxoDB (BERNSTEIN et al., 2018). Twenty-nine samples were identified as non-clonal, however phylogenetic network analyses performed revealed that the majority of the samples were grouped with clonal type III lineage, consistent with other studies conducted in South America (SHWAB et al., 2014). In our work, the genotyped samples were type III allele for all markers except for SAG-1 (type I for Rat1Arg and type II/III for Rat2Arg) and were identified as \#48 and \#2 (likely) The same genotypes were previously described in Argentina: \#48 in samples from a rabbit (Oryctolagus cuniculus) and chickens (Gallus gallus domesticus) in Buenos Aires (BERNSTEIN et al., 2018), and \#2 from meerkats (Suricata suricatta), one kangaroo (Macropus rufus), and three cats (Felis silvestris catus) in Buenos Aires, and three chickens (Gallus gallus domesticus) in Buenos Aires and Entre Rios provinces (BASSO et al., 2009; BERNSTEIN et al., 2018; MORE et al., 2010). In the case of the rabbit, meerkats and the kangaroo, the T. gondii infection was fatal (BASSO et al., 2009; BERNSTEIN et al., 2018; MORE et al., 2010).

In Argentina, several studies have been conducted to isolate and genotype $T$. gondii from different animal species from different regions (BASSO et al., 2009; MORE et al., 2012; PARDINI et al., 2016). As stated before, samples from Buenos Aires province showed clonal genotypes as well as non-clonal genotypes grouped with type III lineage. Additionally, different regions showed different predominance of genotypes (BERNSTEIN et al., 2018). The samples obtained in our study correlates with other samples obtained from the same region/province (BASSO et al., 2009; BERNSTEIN et al., 2018; MORE et al., 2010; PARDINI et al., 2016).

In Brazil, a study analyzed $181 R$. rattus and one $M$. musculus to investigate the role of rodents in the epidemiology of toxoplasmosis 
by IFAT and mice bioassay. A T. gondii prevalence of $8.8 \%$ was detected. Four isolates from tissues were obtained, and the genotyping by nPCR-RFLP was performed using the same markers used in this study plus CS3. Genotyping revealed that all isolates were non-clonal (\# 14 and \# 21, with predominance of type III alleles) (RUFFOLO et al., 2016). These allele combinations are frequently observed for T. gondii isolates from South America (BERNSTEIN et al., 2018; RAJENDRAN et al., 2012). In the present study a higher proportion of seropositive animals were detected, probably due to the environment conditions where rodents were sampled. Also, a slightly higher proportion of parasites in tissues were detected compared to mice bioassay performed in Brazil (2.2\%) (RUFFOLO et al., 2016). The T. gondii genotypes observed in rodents from Brazil were also identified in animals and humans from Argentina (BERNSTEIN et al., 2018).

In a study performed in China, 123 synanthropic rodents were analyzed by $T$. gondii PCR and detected $23.6 \%$ positive samples, with proportions of positive samples of $22.6 \%$ in $M$. musculus and $23.9 \%$ in $R$. novergicus. The genotyping by nPCR-RFLP was complete in seven samples, all identified as non-clonal (ToxoDB \#9) (YAN et al., 2014), similar scenario as in South America (WEISS \& KIM, 2014). Considering that these authors analyzed by PCR exactly the same number of samples as we have, a higher proportion (7 fold) of positive samples was observed in Chinese rodents. The sampled area in China has a higher population and concentration than Gran La Plata sampled area (YAN et al., 2014). Probably, overcrowding urban environments facilitates the $T$. gondii infection in synanthropic rodent populations by scavenging and cannibalism behavior.

Several studies investigated the role of rodents in the epidemiology of neosporosis, indicating the presence of positive animals by serological and molecular studies (FERROGLIO et al., 2007; HUANG et al., 2004; JENKINS et al., 2007). In this study, antibodies against $N$. caninum were found in only one M. musculus of 78 (1.28\%), while molecular studies were negative in all cases. Unfortunately the serum volume obtained from this animal was not enough to perform another serological test such as immunoblot, in order to confirm the IFAT result. Possibly these differences are related to the rodent habitat, since in this case they came from peri-urban areas, while rodents from other studies inhabited cattle farms with $N$. caninum abortion, where the environmental contamination with $N$. caninum oocysts could be an important source of infection (FERROGLIO et al., 2007; HUANG et al., 2004; JENKINS et al., 2007).

Disorganized population growth and development of towns, cities and megalopolises lead to basic sanitation problems and offer ideal conditions for the establishment of synanthropic rodent populations (BRASIL, 2002). The free-living animals such as stray cats, dogs and rodents could be used as sentinels of environmental spreading with $T$. gondii and $N$. caninum in densely built urban areas as they are exposed to all the infective forms of the parasite and feed on various sources of food on the ground (HUGHES et al., 2006; MEERBURG et al., 2012).

Areas involved in this study present partial or total lack of sanitation services, and the presence of precarious and critical overcrowding homes (OYHENART et al., 2007). Also, there is a high number of dogs and cats without responsible care. Probably such conditions contribute to a higher exposure of humans and animals to the different infecting forms of the studied protozoa that represent a sanitary risk. In Buenos Aires Province, the registered rate of human toxoplasmosis was $49 \%$ in pregnant women (CARRAL et al., 2008) and specific antibodies were detected in $35 \%$ of blood donors (from Ciudad Autónoma de Buenos Aires) (DURLACH et al., 2008).

To our knowledge, this is the first report of serology and molecular study of $T$. gondii and $N$. caninum, and genetic characterization of $T$. gondii in synanthropic rodents in Argentina. The results of the present study revealed a wide distribution of $T$. gondii and less for $N$. caninum, in synanthropic rats and mice in the studied area. Two different atypical allele combinations (most type III alleles) genotypes of $T$. gondii were identified, which had been previously reported in other animals in the same region. Isolates with similar allele combinations have demonstrated high-moderate virulence in mice bioassays. These results provide basic information for greater prevention and control of toxoplasmosis in animals and humans. In this context, synanthropic rodents behave as sentinels of zoonotic diseases and could help implement measures to reduce risks for human and animal infection.

\section{Acknowledgements}

We would like to thank to Emilio Topa for the preparation of the tissue fragments (slides), and Isidoro Ercoli and Selva Peñaloza for their excellent technical assistance. This study was funded by Proyectos de Investigación Orientados (Project ID: PIO 13420130100013CO), from Consejo Nacional de Investigaciones Cientificas y Técnicas (CONICET) and Universidad Nacional de La Plata (UNLP).

\section{References}

Basso W, More G, Quiroga MA, Pardini L, Bacigalupe D, Venturini $\mathrm{L}$, et al. Isolation and molecular characterization of Toxoplasma gondii from captive slender-tailed meerkats (Suricata suricatta) with fatal toxoplasmosis in Argentina. Vet Parasitol 2009; 161(3-4): 201-206. http:// dx.doi.org/10.1016/j.vetpar.2009.01.006. PMid:19201541.

Bernstein M, Pardini L, More G, Unzaga JM, Su C, Venturini MC. Population structure of Toxoplasma gondii in Argentina. Infect Genet Evol 2018; 65: 72-79. http://dx.doi.org/10.1016/j.meegid.2018.07.018. PMid:30030206.

Brasil. Manual de controle de roedores. Brasília: FUNASA; 2002.130 p.

Campero LM, Gos ML, Moore DP, Regidor-Cerrillo J, Unzaga JM, More G, et al. Microsatellite pattern analysis of Neospora caninum from a naturally infected goat fetus. Vet Parasitol 2018; 255: 58-60. http:// dx.doi.org/10.1016/j.vetpar.2018.03.024. PMid:29773137.

Campero LM, Venturini MC, Moore DP, Massola L, Lagomarsino H, Garcia B, et al. Isolation and molecular characterization of a new Neospora caninum isolate from cattle in Argentina. Exp Parasitol 2015; 155: 8-12. http://dx.doi.org/10.1016/j.exppara.2015.04.009. PMid:25913666.

Carral L, Kaufer F, Durlach R, Freuler C, Olejnik P, Nadal M, et al. Estudio multicéntrico para la prevención de la toxoplasmosis prenatal en Buenos Aires. Medicina 2008; 68(6): 417-422. PMid:19147421. 
Dellarupe A, Regidor-Cerrillo J, Jimenez-Ruiz E, Schares G, Unzaga $\mathrm{JM}$, Venturini MC, et al. Clinical outcome and vertical transmission variability among canine Neospora caninum isolates in a pregnant mouse model of infection. Parasitology 2014; 141(3): 356-366. http://dx.doi. org/10.1017/S0031182013001479. PMid:24148606.

Dubey JP, Frenkel JK. Toxoplasmosis of rats: a review, with considerations of their value as an animal model and their possible role in epidemiology. Vet Parasitol 1998; 77(1): 1-32. http://dx.doi.org/10.1016/S03044017(97)00227-6. PMid:9652380.

Dubey JP, Schares G, Ortega-Mora LM. Epidemiology and control of neosporosis and Neospora caninum. Clin Microbiol Rev 2007; 20(2): 323-367. http://dx.doi.org/10.1128/CMR.00031-06. PMid:17428888.

Dubey JP. Toxoplasmosis of animals and humans. 2nd ed. Boca Raton: CRC Press; 2010.

Durlach R, Kaufer F, Carral L, Freuler C, Ceriotto M, Rodriguez M, et al. Consenso argentino de toxoplasmosis congénita. Medicina 2008; 68(1): 75-87. PMid:18416325.

Ferroglio E, Pasino M, Romano A, Grande D, Pregel P, Trisciuoglio A. Evidence of Neospora caninum DNA in wild rodents. Vet Parasitol 2007; 148(3-4): 346-349. http://dx.doi.org/10.1016/j.vetpar.2007.06.031. PMid:17651897.

Huang CC, Yang CH, Watanabe Y, Liao YK, Ooi HK. Finding of Neospora caninum in the wild brown rat (Rattus norvegicus). Vet Res 2004; 35(3): 283-290. http://dx.doi.org/10.1051/vetres:2004010. PMid:15210077.

Hughes JM, Williams RH, Morley EK, Cook DA, Terry RS, Murphy RG, et al. The prevalence of Neospora caninum and co-infection with Toxoplasma gondii by PCR analysis in naturally occurring mammal populations. Parasitology 2006; 132(1): 29-36. http://dx.doi.org/10.1017/ S0031182005008784. PMid:16393351.

Instituto Nacional de Estadística y Censos de la República Argentina - INDEC [online]. 2018 [cited 2018 Oct 19]. Available from: https:// www.indec.gov.ar

Jenkins MC, Parker C, Hill D, Pinckney RD, Dyer R, Dubey JP. Neospora caninum detected in feral rodents. Vet Parasitol 2007; 143(2): 161-165. http://dx.doi.org/10.1016/j.vetpar.2006.08.011. PMid:16997474.

McCann CM, Vyse AJ, Salmon RL, Thomas D, Williams DJ, McGarry JW, et al. Lack of serologic evidence of Neospora caninum in humans, England. Emerg Infect Dis 2008; 14(6): 978-980. http://dx.doi.org/10.3201/ eid1406.071128. PMid:18507920.

Meerburg BG, De Craeye S, Dierick K, Kijlstra A. Neospora caninum and Toxoplasma gondii in brain tissue of feral rodents and insectivores caught on farms in the Netherlands. Vet Parasitol 2012; 184(2-4): 317 320. http://dx.doi.org/10.1016/j.vetpar.2011.09.001. PMid:21958437.

Moré G, Basso W, Bacigalupe D, Venturini MC, Venturini L. Diagnosis of Sarcocystis cruzi, Neospora caninum, and Toxoplasma gondii infections in cattle. Parasitol Res 2008; 102(4): 671-675. http://dx.doi.org/10.1007/ s00436-007-0810-6. PMid:18066600.

Moré G, Maksimov P, Pardini L, Herrmann DC, Bacigalupe D, Maksimov A, et al. Toxoplasma gondii infection in sentinel and free-range chickens from Argentina. Vet Parasitol 2012; 184(2-4): 116-121. http://dx.doi. org/10.1016/j.vetpar.2011.09.012. PMid:21962965.

Moré G, Pardini L, Basso W, Machuca M, Bacigalupe D, Villanueva MC, et al. Toxoplasmosis and genotyping of Toxoplasma gondii in Macropu rufus and Macropus giganteus in Argentina. Vet Parasitol 2010; 169(1-2): 57-61. http://dx.doi.org/10.1016/j.vetpar.2009.12.004. PMid:20045255.

Oyhenart E, Torres M, Quintero F, Luis M, Cesani M, Zucchi M, et al. Estado nutricional y composición corporal de niños pobres residentes en barrios perifericos de La Plata (Argentina). Rev Panam Salud Publica 2007 22(3): 194-201. http://dx.doi.org/10.1590/S1020-49892007000800006. PMid:18062854.

Pardini L, More G, Rudzinski M, Gos ML, Campero LM, Meyer A, et al. Toxoplasma gondii isolates from chickens in an area with human toxoplasmic retinochoroiditis. Exp Parasitol 2016; 166: 16-20. http:// dx.doi.org/10.1016/j.exppara.2016.03.006. PMid:26968777.

Pena HF, Gennari SM, Dubey JP, Su C. Population structure and mousevirulence of Toxoplasma gondii in Brazil. Int J Parasitol 2008; 38(5): 561569. http://dx.doi.org/10.1016/j.ijpara.2007.09.004. PMid:17963770.

Pritchard MH, Kruse GO. The collection and preservation of animal parasites. Nebraska: The Harold W. Manter Laboratory, University of Nebraska Press; 1982. 141 p. (Technical Bulletin; vol. 1).

Rajendran C, Su C, Dubey JP. Molecular genotyping of Toxoplasma gondii from Central and South America revealed high diversity within and between populations. Infect Genet Evol 2012; 12(2):359-368. http:// dx.doi.org/10.1016/j.meegid.2011.12.010. PMid:22226702.

Ruffolo BB, Toledo RS, Martins FD, Bugni FM, Costa L, Marana ER, et al. Isolation and genotyping of Toxoplasma gondii in seronegative urban rats and presence of antibodies in communicating dogs in Brazil. Rev Inst Med Trop São Paulo 2016; 58: 28. http://dx.doi.org/10.1590/ s1678-9946201658028. PMid:27074322.

Shwab EK, Zhu XQ, Majumdar D, Pena HF, Gennari SM, Dubey JP, et al. Geographical patterns of Toxoplasma gondii genetic diversity revealed by multilocus PCR-RFLP genotyping. Parasitology 2014; 141(4): 453-461. http://dx.doi.org/10.1017/S0031182013001844. PMid:24477076.

Su C, Zhang X, Dubey JP. Genotyping of Toxoplasma gondii by multilocus PCR-RFLP markers: a high resolution and simple method for identification of parasites. Int J Parasitol 2006; 36(7): 841-848. http:// dx.doi.org/10.1016/j.ijpara.2006.03.003. PMid:16643922.

ToxoDB [online]. 2018 [cited 2018 Oct 19]. Available from: www. toxodb.org/

Weiss LM, Kim K. Toxoplasma Gondii: the model Apicomplexan: perspectives and methods. London: Academic Press; 2014.

Yan C, Liang LJ, Zhang BB, Lou ZL, Zhang HF, Shen X, et al. Prevalence and genotyping of Toxoplasma gondii in naturally-infected synanthropic rats (Rattus norvegicus) and mice (Mus musculus) in eastern China. Parasit Vectors 2014; 7(1): 591. http://dx.doi.org/10.1186/s13071-014-0591-6. PMid:25515133. 